\title{
Investigation of Intestinal Protozoon Prevalence in Immunocompromised Patients at a University Hospital
}

\author{
Bir Üniversite Hastanesinde Immünsüpresif Hastalardaki İntestinal \\ Protozoon Prevalansinin Araştırılması
}

(1) Filiz Kaya ${ }^{1}$, (1) Ahmet Çağkan İnkaya², (1) Sercan Aksoy ${ }^{3}$, (1) Osman Abbasoğlu ${ }^{4}$, (1) Ali İhsan Ertenli ${ }^{5}$,

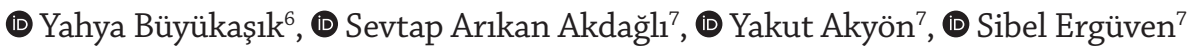

${ }^{1}$ Ankara Training and Research Hospital, Clinic of Medical Microbiology, Ankara, Turkey

${ }^{2}$ Hacettepe University Faculty of Medicine, Department of Infectious Diseases, Ankara, Turkey

${ }^{3}$ Hacettepe University Faculty of Medicine, Department of Medical Oncology, Ankara, Turkey

${ }^{4}$ Hacettepe University Faculty of Medicine, Department of General Surgery, Ankara, Turkey

${ }^{5}$ Hacettepe University Faculty of Medicine, Department of Internal Diseases Rheumatology Subdivision, Ankara, Turkey ${ }^{6}$ Hacettepe University Faculty of Medicine, Department of Internal Diseases Hematology Subdivision, Ankara, Turkey ${ }^{7}$ Hacettepe University Faculty of Medicine, Department of Medical Microbiology, Ankara, Turkey

Cite this article as: Kaya F, İnkaya AÇ, Aksoy S, Abbasoğlu O, Ertenli Aİ, Büyükaşık Y, Arıkan Akdağlı S, Akyön Y, Ergüven

S. Investigation of Intestinal Protozoon Prevalence in Immunocompromised Patients at a University Hospital.

Turkiye Parazitol Derg 2021;45(1):39-44

\section{ABSTRACT}

Objective: Immunocompromised patients are at a greater risk of developing intestinal parasite infections. In this study, we examined the presence of Enterocytozoon bieneusi, Encaphalitozoon intestinalis and other intestinal protozoa in stool samples of immunosuppressed patients.

Methods: A total of 100 stool samples were obtained from patients receiving chemotherapy because of solid organ tumour with haematological malignancies and those receiving immunosuppressive treatment because of rheumatic diseases, organ transplant patients and patients receiving treatment for HIV-related infections. Stool samples were examined by using the native-lugol method in which the stool concentration, modified Kinyoun acid-fast and trichrome staining methods and parasite presence were analysed. The stool samples were also examined for the presence of Enterocytozoon bieneusi and Encephalitozoon intestinalis using an indirect fluorescent antibody method.

Results: Intestinal parasites were detected in $12 \%$ of all patients. The distribution of intestinal parasites in patients were $7 \%$ Blastocystis spp., $2 \%$ Blastocystis spp. + Dientamoeba fragilis, $1 \%$ Blastocystis spp. + Entamoeba coli, $1 \%$ Blastocystis spp. + Giardia intestinalis and $1 \%$ G. intestinalis. Microsporidia spp. were detected in $4 \%$ of all patients by the IFAT method and in $8 \%$ of all patients by calcoflour staining method.

Conclusion: In our study, the most prevalent parasite detected in the immunosuppressed patients was Blastocystis spp. The pathogenesis of Blastocystis spp. remains to be controversial, and their role in immunocompromised patients continues to remain unknown. Although these rates detected in our study are similar to the prevalence in the normal population, it is important to study these microorganisms in immunocompromised patients in terms of the associated decreasing morbidity and mortality rates. Keywords: Immunosuppression, Microsporidia spp., parasites, Blastocystis spp.

\section{Öz}

Amaç: Bağışıklık sistemi baskılanmış hastalar, fırsatçı bağırsak parazit enfeksiyonları bakımından risk altındadır. Bu çalışmada, bağışıklık sistemi baskılanmış hastaların dışkı örneklerinde Enterocytozoon bieneusi ve Encephalitozoon intestinalis ile diğer bağırsak protozoonlarının varlığının incelenmesi amaçlanmıștır.

Yöntemler: Solid organ tümörü nedeniyle kemoterapi alan ya da hematolojik malignitesi olan, romatolojik hastalıklar nedeniyle immünsüpresif tedavi gören, organ nakli yapılan ve HIV enfeksiyonu nedeniyle tedavi almakta olan toplam 100 hastadan dişkı

Received/Geliş Tarihi: 09.03.2020 Accepted/Kabul Tarihi: 16.10.2020

Address for Correspondence/Yazışma Adresi: Filiz Kaya, Ankara Training and Research Hospital, Clinic of Medical Microbiology, Ankara, Turkey

Phone/Tel.: +90 5054576712 E-mail/E-posta: filizdemirelkaya@gmail.com ORCID ID: orcid.org/0000-0002-3513-8347

${ }^{\circ}$ Copyright 2021 Turkish Society for Parasitology - Available online at www.turkiyeparazitolderg.org

C Telif hakkı 2021 Türkiye Parazitoloji Derneği - Makale metnine www.turkiyeparazitolderg.org web sayfasından ulașılabilir. 
örnekleri alınmıştır. Dışkı örnekleri nativ-lugol yöntemi, dışkı konsantrasyon, modifiye Kinyoun asit-fast ve trikrom boyama yöntemleriyle incelenerek protozoon varlığı araştırılmıştır. Dışkı örnekleri, indirekt floresan antikor yöntemi kullanılarak Enterocytozoon bieneusi ve Encephalitozoon intestinalis varlığı açısından da incelenmiştir.

Bulgular: Hastaların \%12'sinde, bir ya da daha fazla sayıda intestinal protozoon saptanmıştır. İntestinal protozoonların dağılımı ise \%7 Blastocystis spp., $\% 2$ Blastocystis spp. + Dientamoeba fragilis, \%1 Blastocystis spp. + Entamoeba coli, \%1 Blastocystis spp. + Giardia intestinalis ve \%1 G. intestinalis şeklindedir. Microsporidia spp. IFA yöntemi ile \%4, kalkoflor boyama ile \%8 oranında saptanmıştır.

Sonuç: Çalışmamızda, immünsüpresif hastalarda en fazla saptanan intestinal protozoon Blastocystis spp.'dir. Blastocystis türlerinin patojenitesi halen tartışmalı olup, immünsüpresif hastalardaki rolü tam olarak bilinmemektedir. Çalışmamızda bulunan bu oranlar normal toplumdaki prevalanslarla benzer olmakla birlikte; bağışıklık sistemi baskılanmış hastalarda bu mikroorganizmaların araştırılması, morbidite ve mortalitenin azaltılması açısından önem taşımaktadır.

Anahtar kelimeler: İmmünsüpresyon, Microsporidia spp., parazit, Blastocystis spp.

\section{INTRODUCTION}

Number of immunocompromised patients continues to increase as a consequence of immunosuppressive therapies for malignancies and immune-mediated disorders, infections with the human immunodeficiency virus (HIV), hematopoietic and solid organ transplants. These patients are at greater risk for developing more severe parasitic infections than are immunocompetent individuals. Although the pathogenesis of parasitic infections in immunosuppression is poorly understood, immunocompromised hosts are more likely to acquire infection, develop severe and disseminated disease and be unable to clear parasites $(1,2)$. Intestinal protozoan infections are more frequently seen in the immunocompromised host. The most common intestinal protozoa in these patients are Cryptosporidium, Cyclospora and Cystoisospora. In recent years, Blastocystis spp. and Microsporidia spp. are reported to be emerging pathogens in the immunocompromised hosts (2).

Cryptosporidium is a coccidian protozoon parasite which may lead to diarrhea in both developed and developing countries. In immunocompetent patients cryptosporidiosis is generally asymptomatic or self-limited, however; in immunocompromised patients it can cause chronic and severe diarrhea and lead to life threatening disease because of dehydration. Extraintestinal manifestations like cholecystitis, pancreatitis and respiratory infection may also be seen in these patients (3-5). The other coccidian protozoa Cyclospora and Cystoisospora are more common in tropical and subtropical areas. Cyclosporiasis may vary from asymptomatic or moderate infection to severe intestinal disease and may present as traveler's diarrhea and as waterborne or foodborne outbreaks. Cyclospora and Cystoisospora infections are more severe, chronic and fatal in immunocompromised patients similar to cryptosporidiosis (6-8).

Microsporidia are obligate intracellular microorganisms which are closely related to fungi (9). Enterocytozoon bieneusi and Encephalitozoon intestinalis are the most common species that cause intestinal microsporidiosis. Although asymptomatic infections or watery diarrhea are common in immunocompetent patients, opportunistic infections including cholangitis, cholecyctitis, non-specific sinusitis and rhinitis may develop in case of immunosuppression $(10,11)$.

In this study, we investigated the existence of intestinal protozoa in the stool samples obtained from immunocompromised patients.

\section{METHODS}

\section{Patients}

A total of 100 adult immunocompromised patients who were receiving immunosuppressive therapies for rheumatic diseases, transplantation or cancer and being treated for hematopoietic malignancies or HIV infection were included in the study. Data on demographic, clinical and laboratory parameters were recorded for each patient.

Protocol of the study was reviewed and approved by Noninterventional Ethics Board/Committee (decision number: G101493-09, date: 05.03.2014). Detailed information about the study was given to each participant in the study and an informed consent form was signed.

\section{Sample Collection and Laboratory Analyses}

One or more consecutive fresh stool samples were collected from the patients and transferred to the laboratory within 30 minutes after defecation. Stool concentration method (Parasep ${ }^{\circledR}$ Fecal Parasite Concentrators, Apacor, USA), direct microscopic examination (saline and iodine), Wheatley's trichrome staining and Kinyoun's acid fast staining methods were performed for identification of intestinal parasites (12-15). The presence of $E$. bieneusi and $E$. intestinalis antigens in the stool samples were investigated by a commercial indirect fluorescent antibody (IFA) kit in accordance with the manufacturer's instructions (Bordier Affinity Products, SA) and calcoflour staining method (16). All tests were performed in parasitology section of department of medical microbiology.

\section{Statistical Analysis}

Because of the low number of the patients, statistical analyses could not be made.

\section{RESULTS}

The age of the patients included in the study ranged from 19 to 76 years and $61 \%$ were male (Table 1 ). Forty-four patients were receiving immunosuppressive therapies for cancers such as lung cancer and breast cancer or being treated for hematopoietic malignancies such as lymphoma. Thirty-seven were receiving immunosuppressive drugs for rheumatic diseases such as ankylosing spondylitis and rheumatoid arthritis. Ten were receiving immunosuppressive therapies for solid organ transplantation. Five had HIV infection and four had hypogammaglobulinemia (Table 2).

Table 1. Age and gender distribution of the patients

\begin{tabular}{|l|l|l|}
\hline Patients & n (\%) & Mean age \\
\hline Female & $39(39 \%)$ & 49.3 \\
\hline Male & $61(61 \%)$ & 46.4 \\
\hline
\end{tabular}


Out of 100 patients, $26 \%$ had diarrhoea, in besides of $74 \%$ of the patients had no symptoms that point to a parasitic infection such as diarrhoea, abdominal pain, nausea or vomiting.

Intestinal parasites were detected in $12 \%$ of the stool samples examined with direct microscopic examination (saline and iodine), Wheatley's trichrome staining and stool concentration methods. The distribution of intestinal parasites in these patients were Blastocystis spp. in 7\% (Figure 1A), Blastocystis spp. plus Dientamoeba fragilis (Figure 1B) in 2\%, Blastocystis spp. plus Entamoeba coli in 1\%, Blastocystis spp. plus Giardia intestinalis in $1 \%$, G. intestinalis in $1 \%$. Out of 12 patients whose stool samples revealed intestinal parasites, eight of them had diarrhea (Table 3). Cryptosporidium, Cyclospora or Cystoisospora species were not detected with Kinyoun's acid fast staining method in any of the patients.

E. intestinalis was found in the $4 \%$ of the immunocompromised patients by using IFAT method (Figure 2A). Microsporidia spp. were detected in the $8 \%$ of the patients by calcoflour staining method (Figure 2B). None of these patients had gastrointestinal symptoms (Table 4).

According to these results, the most common parasite detected in immunosuppressed patients was Blastocystis spp. with a rate of $11 \%$. Among these patients $63.6 \%$ had diarrhea.

One of the limitations of this study was the lack of control group. Due to the absence of a control group, statistical analysis could not be performed.

\begin{tabular}{l|l|l|}
\hline Table 2. Clinical distribution of the patients \\
\hline Department & Diagnosis & n (\%) \\
\hline Rheumatology & Rheumatic diseases & $37(37 \%)$ \\
\hline Hematology & Hematopoietic malignancies & $26(26 \%)$ \\
\hline Medical oncology & Cancers & $18(18 \%)$ \\
\hline General surgery & Transplantation & $10(10 \%)$ \\
\hline Infectious diseases & HIV infection & $5(5 \%)$ \\
\hline Infectious diseases & Hypogammaglobulinemia & $4(4 \%)$ \\
\hline HIV: Human immunodeficiency virus \\
\hline
\end{tabular}


\section{DISCUSSION}

Immunosuppression is an important risk factor for developing infections. There is a wide range of factors that causes immunosuppression in patients. Genetic deficiencies in functional compartment of the immune system such as common variable immunodeficiency (CVID), selective IgA deficiency and X-linked agammaglobulinemia is called primary immunodeficiency

\section{Table 3. Distribution of intestinal parasites detected in immunocompromised patients}

\begin{tabular}{|c|c|c|c|c|}
\hline & Department & Patient's diagnosis & Diarrhea & Intestinal parasites \\
\hline 1 & Infectious diseases & Hypogammaglobulinemia & + & G. intestinalis + Blastocystis spp. \\
\hline 2 & Infectious diseases & Hypogammaglobulinemia & + & G. intestinalis \\
\hline 3 & Infectious diseases & Hypogammaglobulinemia & + & E. coli + Blastocystis spp. \\
\hline 4 & Medical oncology & Endometrial cancer & + & D. fragilis + Blastocystis spp. \\
\hline 5 & Rheumatology & Ankylosing spondylitis & + & D. fragilis + Blastocystis spp. \\
\hline 6 & Rheumatology & Ankylosing spondylitis & + & Blastocystis spp. \\
\hline 7 & Rheumatology & Ankylosing spondylitis & + & Blastocystis spp. \\
\hline 8 & Rheumatology & Ankylosing spondylitis & - & Blastocystis spp. \\
\hline 9 & Rheumatology & Rheumatoid arthritis & + & Blastocystis spp. \\
\hline 10 & Rheumatology & Rheumatoid arthritis & - & Blastocystis spp. \\
\hline 11 & Hematology & Chronic lymphocytic leukemia & - & Blastocystis spp. \\
\hline 12 & Hematology & Chronic lymphocytic leukemia & - & Blastocystis spp. \\
\hline
\end{tabular}





diseases. Secondary immunodeficiencies may develop due to another illness, condition or as a result of treatment. Metabolic diseases (e.g. diabetes mellitus, protein-losing enteropathy), treatments for malignancies, rheumatologic and autoimmune diseases, transplantation and HIV infection are among the causes of secondary immunodeficiencies (17).

Intestinal parasitic infections (IPI) are important causes of morbidity and mortality in patients with immunodeficiency. In this study, we aimed to investigate the prevalence of intestinal parasites and Microsporidia spp. in patients with immunocompromising conditions.

In a study conducted to investigate the prevalence of intestinal pathogens in patients with different immunological status, intestinal parasites were detected in both immunocompetent (6.5\%) and immunocompromised patients (4.6\%) (18). In another study held in Iran, the stool samples of 135 hemodialysis patients, 50 renal transplant recipients, 60 cancer patients and $20 \mathrm{HIV} /$ AIDS patients were investigated for IPI. Intestinal parasites were found in $11.7 \%$ of the patients and Blastocystis spp. (4.2\%) were the most prevalent parasite. In this study, the highest infection rate was detected among HIV/AIDS patients (25\%). So indeed, HIV-infected patients are more susceptible to opportunistic intestinal infections (19). Accordingly, in a prospective study, out of 137 HIV-infected patients, $78.8 \%$ were diagnosed IPI and the most prevalent parasites were Blastocystis spp. (26.3\%), E. histolytica/dispar (12.4\%) and G.intestinalis (8.8\%) (20). In a study conducted in Turkey, 65 HIV-positive patients were investigated for the presence of intestinal parasites and the distribution of the parasites was Cryptosporidium spp. (21.5\%), Cyclospora spp. (3.1\%) and Blastocystis spp. (10.8\%) (21). In our study, five HIVinfected patients' stool samples did not reveal any intestinal parasite, that's probably due to the low number of patients.

Table 4. Distribution of intestinal parasites detected in immunocompromised patients, according to gender, age, presence of diarrhea and diagnosis

\begin{tabular}{|c|c|c|c|c|c|}
\hline & Blastocystis spp. & G. intestinalis & D. fragilis & $\begin{array}{l}\text { Microsporidia spp. } \\
\text { (Calcoflour staining) }\end{array}$ & $\begin{array}{l}\text { E. intestinalis } \\
\text { (Microsporidia IFAT) }\end{array}$ \\
\hline \multicolumn{6}{|l|}{ Gender } \\
\hline Female $(\mathrm{n}=39)$ & 4 & - & 1 & 2 & - \\
\hline Male $(n=61)$ & 7 & 2 & 1 & 6 & 4 \\
\hline \multicolumn{6}{|l|}{ Age } \\
\hline $18-40(n=32)$ & 3 & 2 & - & 5 & 2 \\
\hline $41-60(n=49)$ & 4 & - & 2 & 3 & 2 \\
\hline$>61(\mathrm{n}=19)$ & 4 & - & - & - & - \\
\hline \multicolumn{6}{|l|}{ Diarrhea } \\
\hline Positive & 7 & 2 & 2 & - & - \\
\hline Negative & 4 & - & - & 8 & 4 \\
\hline \multicolumn{6}{|l|}{ Diagnosis } \\
\hline Rheumatic diseases & 6 & - & 1 & 4 & 3 \\
\hline Hematopoietic malignancies & 2 & - & - & 1 & - \\
\hline Cancers & 1 & - & 1 & - & - \\
\hline Transplantation & - & - & - & 3 & 1 \\
\hline HIV infection & - & - & - & - & - \\
\hline Hypogammaglobulinemia & 2 & 2 & - & - & - \\
\hline
\end{tabular}


Hypogammaglobulinemia is a disorder that is characterized by deficiency of immunoglobulins in the blood and CVID is the most common cause. Patients with hypogammaglobulinemia have an increased susceptibility to pathogens affecting mucous membranes of gastrointestinal tract (22). In a study conducted in Turkey, 26 of 37 CVID patients had diarrhea and intestinal parasites were detected in 13 of them. The most common parasites detected in this study were Cryptosporidium spp. (69.2\%) and G. intestinalis (53.8\%) (23). In the current study, four patients with hypogammaglobulinemia had diarrhea and three of them were diagnosed with IPI. Blastocystis spp. and G. intestinalis were detected in these patients' stool samples; however; Cryptosporidium spp. were not found in any of the patients. Essentially, intestinal coccidian parasites are common cause of diarrhea in immunocompromised individuals. In a study, out of 350 immunocompromised patients, Cryptosporidium spp. and $C$. belli oocysts were detected in three $(0.9 \%)$ and four (1.1\%), respectively (24). In another study, Cryptosporidium spp. were found in six (10.1\%) and C. belli in four (6.7\%) of 59 HIV-infected patients (25). Similarly, the higher prevalence of Cryptosporidium spp. in pediatric oncology patients with diarrhea compared to non-oncology patients is reported in a previous study (26). Taş Cengiz et al. (27) reported $C$. belli infection determined in both immunosuppressed and immunocompetent children. In our study, three (6.8\%) of the 44 oncology/hematology patients' stool samples revealed Blastocystis spp.; although; none of them had intestinal coccidian parasites.

Rheumatologic and autoimmune diseases are the other causes of immunosuppression due to the use of immunomodulatory or immunosuppressive therapies (28). These patients have an increased risk of severe manifestations of IPI (29). Some intestinal cryptosporidiosis cases reported in patients using low-dose prednisone for rheumatoid arthritis and adalimumab for ankylosing spondylitis (30,31). In a study conducted in 36 patients with rheumatoid arthritis and ankylosing spondylitis, the frequencies of intestinal parasites were $25 \%$ and $33 \%$, respectively. The difference between intestinal parasite detection rates in healthy and patient groups was not found statistically significant (32). In our study, six (16.2\%) of the 37 patients receiving immunosuppressive therapies for rheumatic diseases had IPI, and Blastocystis were detected in all of these patients. Blastocystis is reported to be associated with a variety of gastrointestinal disorders; although; the pathogenic role of parasite is still controversial (33). In a study held in China, out of 381 stool samples collected from cancer patients, $7.1 \%$ and $1.3 \%$ were found positive for Blastocystis and E. bieneusi, respectively. In addition, significant association of Blastocystis with diarrhea was found in cancer patients (34). Similarly, Blastocystis were detected in $11 \%$ of the immunocompromised patients and $63.6 \%$ of them had diarrhea in our study.

Intestinal Microsporidia may cause severe and life-threatening infection in patients with immunodeficiency. In a previous study, E. bieneusi was detected in $14.5 \%$ (19/131) of the immunocompromised patients and $1.47 \%$ (1/68) of the immunocompetent individuals. A significant difference was detected between patients with immunodeficiency and healthy individuals in terms of prevalence of E. bieneusi (35). In another study, out of 310 samples collected from immunocompromised patients, 20\% (62/310) were positive for E. bieneusi and $8.3 \%$
(26/310) were detected as other Encephalitozoon species by using molecular methods (36). In a study conducted with 98 rheumatology patients and 92 healthy individuals, Microsporidia spp. were identified significantly higher in patients in underlying immunosuppression; although; the prevalence of other intestinal parasites was similar in both patient and control groups (37). In another study, the prevalence of E. intestinalis and E. bieneusi in cancer patients under chemotherapy was detected very high (38). In our study, intestinal Microsporidia spp. were found mostly in rheumatology patients. Although it is reported that E. bieneusi is the most common Microsporidia species isolated from immunocompromised patients (39), in our study, E. intestinalis was identified more, but; none of the patients whose stool samples revealed Microsporidia had diarrhea. On the other hand, one or more intestinal parasites were detected in $30.8 \%$ of immunocompromised patients with diarrhea. Therefore, intestinal parasites should be investigated in these patients regardless of the presence of gastrointestinal symptoms.

Varying intestinal parasite prevalence rates in the previous studies as compared to that in the present study may be due to the patients' immunodeficiency level, number of patients enrolled the studies or methods used. The limitations of our study were the low number of patients and the inability to use molecular methods, but, our results may help to indicate the prevalence of Microsporidia spp. and intestinal parasites in our region. One of the other shortcomings of the study is that a healthy control group could not be included in the study. Another major limitation is the relatively low number of patients with diarrhea which is a further challenge in interpretation of the results in terms of existence of the opportunistic pathogen in relation to its pathogenicity on diarrhea.

\section{CONCLUSION}

When all results are evaluated, Blastocystis were the most prevalent intestinal parasite in $11 \%$ and Microsporidia spp. in $10 \%$ of the immunocompromised patients. Although these rates in our study are similar to those in the normal population, the investigation of these microorganisms in patients with immunodeficiency or individuals undergoing immunosuppressive drug treatment is important for reducing severe infections and mortality.

\section{INFORMATION}

Poster presentation in the 4. National Clinical Microbiology Congress. 08-12 Oct 2017, Ankara, Turkey.

\section{* Ethics}

Ethics Committee Approval: Protocol of the study was reviewed and approved by Non-interventional Ethics Board/Committee (decision number: G101493-09, date: 05.03.2014).

Informed Consent: Detailed information about the study was given to each participant in the study and an informed consent form was signed.

Peer-review: Internally peer-reviewed.

\section{* Authorship Contributions}

Surgical and Medical Practices: A.Ç.İ., S.A., O.A., A.İ.E., Y.B., Concept: F.K., A.Ç.İ., S.E., Design: F.K., S.E., Data Collection or Processing: F.K., A.Ç.İ., S.A., O.A., A.İ.E., Y.B., Analysis or 
Interpretation: F.K., S.A.A., Y.A., S.E., Literature Search: F.K., Writing: F.K.İ, A.Ç.İ., S.A.A., Y.A., S.E.

Conflict of Interest: No conflict of interest was declared by the authors.

Financial Disclosure: Research Fund of Hacettepe University supported this project (project number: 1323, 2014).

\section{REFERENCES}

1. Stark D, Barratt JL, van Hal S, Marriott D, Harkness J, Ellis JT. Clinical significance of enteric protozoa in the immunosuppressed human population. Clin Microbiol Rev 2009; 22: 634-50.

2. Marcos LA, Gotuzzo E. Intestinal protozoan infections in the immunocompromised host. Curr Opin Infect Dis 2013; 26: 295-301.

3. Vanathy K, Parija SC, Mandal J, Hamide A, Krishnamurthy S. Cryptosporidiosis: A mini review. Trop Parasitol 2017; 7: 72-80.

4. Custodio H. Protozoan Parasites. Pediatr Rev 2016; 37: 59-69.

5. Mahmoudi MR, Ongerth JE, Karanis P. Cryptosporidium and cryptosporidiosis: The Asian perspective. Int J Hyg Environ Health 2017; 220: 1098-109.

6. Ortega YR, Sanchez R. Update on Cyclospora cayetanensis, a food-borne and waterborne parasite. Clin Microbiol Rev 2010; 23: 218-34.

7. Herwaldt BL. Cyclospora cayetanensis: a review, focusing on the outbreaks of cyclosporiasis in the 1990s. Clin Infect Dis 2000; 31: 1040-57.

8. Siddiqui ZA. An overview of parasitic infections of the gastro-intestinal tract in developed countries affecting immunocompromised individuals. J Parasit Dis 2017; 41: 621-6.

9. Han B, Weiss LM. Microsporidia: Obligate Intracellular Pathogens Within the Fungal Kingdom. Microbiol Spectr 2017; 5: 10.1128

10. Field AS, Milner DA Jr. Intestinal microsporidiosis. Clin Lab Med 2015; 35: $445-59$

11. Ghoshal U, Khanduja S, Pant P, Prasad KN, Dhole TN, Sharma RK, et al. Intestinal microsporidiosis in renal transplant recipients: Prevalence, predictors of occurrence and genetic characterization. Indian $\mathrm{J}$ Med Microbiol 2015; 33: 357-63.

12. Zeeshan M, Zafar A, Saeed Z, Irfan S, Sobani ZA, Shakoor S, et al. Use of "Parasep filter fecal concentrator tubes" for the detection of intestinal parasites in stool samples under routine conditions. Indian $\mathrm{J}$ Pathol Microbiol 2011; 54: 121-3.

13. Turgay N. Özel boyama yöntemleri. Korkmaz M, Ok ÜZ (Ed.). Parazitolojide Laboratuvar. Türkiye Parazitoloji Derneği. 2011: s.37-40.

14. Kır B, Kaçmaz G, Karaman Ü, Direkel Ş, Akdemir C, Baldemir A, Güçlüer Ildir N. Comparison of The Modified Trichrome Stain Method With Wheatley's Trichrome Stain Methods (article in Turkish). Klinik Tip Aile Hekimliği Dergisi 2018; 10: 15-8.

15. Aydın M, Adıyaman G, Kaya T, Kuştimur S, Doğruman AL F. Comparison of Conventional and Commercial Trichrome Staining Methods for Detecting Protozoan in Stool Samples (article in Turkish). Kafkas Univ Vet Fak Derg 2012; 18: 155-9.

16. Ghoshal U, Khanduja S, Pant P, Ghoshal UC. Evaluation of Immunoflourescence antibody assay for the detection of Enterocytozoon bieneusi and Encephalitozoon intestinalis. Parasitol Res 2016; 115: 3709-13.

17. Dropulic LK, Lederman HM. Overview of Infections in the Immunocompromised Host. Microbiol Spectr 2016; 4.

18. Bednarska M, Jankowska I, Pawelas A, Piwczyńska K, Bajer A, WolskaKuśnierz B, et al. Prevalence of Cryptosporidium, Blastocystis, and other opportunistic infections in patients with primary and acquired immunodeficiency. Parasitol Res 2018; 117: 2869-79.

19. Rasti S, Hassanzadeh M, Hooshyar H, Momen-Heravi M, Mousavi SGA, Abdoli A. Intestinal parasitic infections in different groups of immunocompromised patients in Kashan and Qom cities, central Iran. Scand J Gastroenterol 2017; 52: 738-41.

20. Paboriboune P, Phoumindr N, Borel E, Sourinphoumy K, Phaxayaseng S, Luangkhot $\mathrm{E}$, et al. Intestinal parasitic infections in HIV-infected patients, Lao People's Democratic Republic. PLoS One 2014; 9: 91452.
21. Zorbozan O, Quliyeva G, Tunalı V, Özbilgin A, Turgay N, Gökengin AD. Intestinal Protozoa in Hiv-Infected Patients: A Retrospective Analysis. Turkiye Parazitol Derg 2018; 42: 187-90.

22. Reust CE. Evaluation of primary immunodeficiency disease in children. Am Fam Physician 2013; 87: 773-8.

23. Uysal S, Tunalı V, Akdur Öztürk E, Ardeniz Ö, Işıkgöz Taşbakan M, Pullukçu H, et al. Incidence of Parasitic Diarrhea in Patients with Common Variable Immune Deficiency. Turkiye Parazitol Derg 2016; 40: 67-71.

24. Salehi Sangani G, Mirjalali H, Farnia S, Rezaeian M. Prevalence of Intestinal Coccidial Infections among Different Groups of Immunocompromised Patients. Iran J Parasitol 2016; 11: 332-8.

25. Assis DC, Resende DV, Cabrine-Santos M, Correia D, Oliveira-Silva MB. Prevalence and genetic characterization of Cryptosporidium spp. and Cystoisospora belli in HIV-infected patients. Rev Inst Med Trop Sao Paulo 2013; 55: S0036-46652013000300149

26. Hijjawi N, Zahedi A, Kazaleh M, Ryan U. Prevalence of Cryptosporidium species and subtypes in paediatric oncology and non-oncology patients with diarrhoea in Jordan. Infect Genet Evol 2017; 55: 127-30.

27. Taş Cengiz Z, Yılmaz H, Çiçek M, Beyhan YE, Dülger AC. Cystoisospora $s p$. Infection Determined in Immunosuppressed and Immunocompetent Children: Three Cases Report. Turkiye Parazitol Derg 2016; 40: 107-9.

28. Rosman Z, Shoenfeld Y, Zandman-Goddard G. Biologic therapy for autoimmune diseases: an update. BMC Med 2013; 11: 88.

29. Braz AS, de Andrade CA, da Mota LM, Lima CM. Recomendações da Sociedade Brasileira de Reumatologia sobre diagnóstico e tratamento das parasitoses intestinais em pacientes com doenças reumáticas autoimunes [Recommendations from the Brazilian Society of Rheumatology on the diagnosis and treatment of intestinal parasitic infections in patients with autoimmune rheumatic disorders]. Rev Bras Reumatol 2015; 55: 368-80.

30. Ramsay DB, Long SE, Ali MA, Entwisle C, Orenstein JM, Rossi C, et al. Isolated gastric cryptosporidiosis in an immunocompetent patient. Dig Dis Sci 2007; 52: 1364-6.

31. Chiuchetta FA. Cryptosporidiosis in a patient with ankylosing spondylitis treated with adalimumab. Rev Bras Reumatol 2010; 50: 328-32.

32. Jimenez-Balderas FJ, Camargo-Coronel A, Gargia-Jaimes J, ZonanaNacach A, Alcantara-Anguianoi I, Carrillo-Becerril L, et al. A study on parasites in Mexican rheumatic disease patients. J Egypt Soc Parasitol 2012; 42: 271-80.

33. Wawrzyniak I, Poirier P, Viscogliosi E, Dionigia M, Texier C, Delbac F, et al. Blastocystis, an unrecognized parasite: an overview of pathogenesis and diagnosis. Ther Adv Infect Dis 2013; 1: 167-78.

34. Zhang W, Ren G, Zhao W, Yang Z, Shen Y, Sun Y, et al. Genotyping of Enterocytozoon bieneusi and Subtyping of Blastocystis in Cancer Patients: Relationship to Diarrhea and Assessment of Zoonotic Transmission. Front Microbiol 2017; 8: 1835

35. Nooshadokht M, Sharifi I, Mohammadi MA, Pirestani M, Afgar A, Mahootchi A et al. Intestinal microsporidiosis in Iran: infection in immune-compromised and immunocompetent patients. Curr Med Mycol 2017; 3: 30-6.

36. Tavalla M, Mardani-Kateki M, Abdizadeh R, Nashibi R, Rafie A, Khademvatan S. Molecular identification of Enterocytozoon bieneusi and Encephalitozoon spp. in immunodeficient patients in Ahvaz, Southwest of Iran. Acta Trop 2017; 172: 107-12

37. Aikawa NE, Twardowsky Ade O, Carvalho JF, Silva CA, Silva IL, Ribeiro $\mathrm{AC}$, et al. Intestinal microsporidiosis: a hidden risk in rheumatic disease patients undergoing anti-tumor necrosis factor therapy combined with disease-modifying anti-rheumatic drugs? Clinics (Sao Paulo) 2011; 66: 1171-5.

38. Hamamcı B, Çetinkaya Ü, Berk V, Kaynar L, Kuk S, Yazar S. Kemoterapi alan kanserli hastalarda Encephalitozoon intestinalis ve Enterocytozoon bieneusi prevalans1 [Prevalence of Encephalitozoon intestinalis and Enterocytozoon bieneusi in cancer patients under chemotherapy]. Mikrobiyol Bul 2015; 49: 105-13

39. Mirjalali H, Mirhendi H, Meamar AR, Mohebali M, Askari Z, Mirsamadi ES, et al. Genotyping and molecular analysis of Enterocytozoon bieneusi isolated from immunocompromised patients in Iran. Infect Genet Evol 2015; 36: 244-9. 